\title{
Andrographolide Induced Apoptosis in NALM-6 Cells Mediated Through the Cell Cycle Arrest and Nuclear Fragmentation
}

\author{
Swadesh Sarkar ${ }^{1,2}$, Priya K Gopal ${ }^{2}$, Santanu Paul²*
}

\section{Swadesh Sarkar ${ }^{1,2}$, Priya K Gopal' $^{2}$, Santanu Paul ${ }^{2 *}$}

'Department of Botany, Chandernagore College, Chandernagore, Hoogly- 712136, West Bengal, INDIA.

'Laboratory of Cell and Molecular Biology, Department of Botany, 35 Ballugunge Circular Road, University of Calcutta, Kolkata-700019, West Bengal, INDIA.

\section{Correspondence}

\section{Santanu Paul}

CAS, Department of Botany, Laboratory of Cell and Molecular Biology, 35 Ballugunge Circular Road, University of Calcutta, Kolkata-700019,West Bengal, INDIA.

Phone no: +919874192648

E-mail: spaul_1971@yahoo.com

History

- Submission Date: 30-08-2017;

- Review completed: 11-09-2017;

- Accepted Date: 20-11-2017

DOI : 10.5530/pj.2018.2.36

Article Available online

http://www.phcogj.com/v10/i2

\section{Copyright}

(C) 2018 Phcog.Net. This is an openaccess article distributed under the terms of the Creative Commons Attribution 4.0 International license.

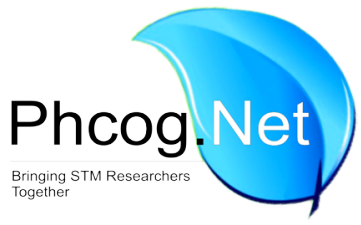

\begin{abstract}
Introduction: Andrographis paniculata is an herb widely cultivated in South and Southeastern Asia. It has been traditionally used to treat infections and other Physiological disorders for several hundreds. We investigated the anti-leukemic potential of Andrographolide (AGP) isolated from the leaves of this plant against an array of cancer cells to investigate its most efficacies in a particular cancer type. Methods: AGP was isolated from Andrographis paniculata leaves by using column chromatography. The structure was further determined by LC-MS, $1 \mathrm{H}$ NMR and 13C NMR. AGP was initially tested against four different cancer cell lines, namely NALM-6 (pre B-ALL), K562 (CML), A549 (lung carcinoma) and MCF-7 (breast carcinoma) using MTT assay at different time points and different concentrations. The effect of the isolated biomolecule was also investigated in inducing apoptosis through the study of cell cycle progression using flow cytometry by PI staining and nuclear fragmentation pattern by DAPI staining and fluorescence microscopy. Results: the spectral analysis of the isolated bio-molecule assured that the compound was AGP. MTT assay data indicated that AGP was most potent to induce cytotoxicity in NALM-6 cells. Further investigation revealed that it effectively induced apoptosis by arresting cell cycle progression and increased the nuclear break down in NALM6 leukemic cells. Conclusion: Our study efficiently demonstrated that the AGP isolated from Andrographis paniculata induced apoptosis in NALM-6 cells, which could be used in the therapeutic intervention of leukemia in the future.
\end{abstract}

Key words: Andrographis paniculata, Andrographolide, Apoptosis, Cell cycle, Cytotoxicity, Leukemia.

\section{INTRODUCTION}

Leukemia is the most common childhood cancer and associated with increased proliferation and decreased apoptosis in neoplastic blood cells. According to Cancer Research (UK), ${ }^{1} 9634$ new cases and 4584 deaths occurred in 2014 from leukemia. Induction of apoptosis is the best strategy to destroy these malignant cells. These cells carry a number of mutations in their genome/proteome, that results in the up-regulation of anti-apoptotic proteins (e.g. Bcl-2, Bcl-XL etc.) as well as down-regulation of different pro-apoptotic proteins (e.g. Bid). Therefore, utilization of multitarget drugs is most important for treating leukemia. Now-a-days a higher percentage of commercial drugs contain active principles from natural sources, particularly from plants for its multiple targets and least side-effects e.g. Paclitaxel, Podophyllotoxin etc.

Andrographis paniculata Nees. (Acanthaceae), commonly known as 'Kalmegh', is a wonder drug and very popular in 'Aurvedic' and 'Siddha' systems of medicine in India for its wide spectrum of biological activities. $^{2}$ Three major labdane type diterpenoids to which the main biological activities of the plant are attributed, are Andrographolide (AGP), 14-Deoxy11,12-didehydroandrographolide and Neoandrogra- pholide (NAGP). ${ }^{3}$ AGP, the major diterpenoid of this plant, has hepatoprotective, hepatostimulant, ${ }^{4}$ anti-inflammatory, ${ }^{5}$ anti-viral ${ }^{6}$ and anti-leukemic activities. $^{7} \quad$ 14-deoxy-11,12-didehydroandrographolide, the second major diterpenoids of this plant, has cardiovascular ${ }^{8}$ and anti-inflammatory ${ }^{9}$ effects. Anti-leukemic activity of this compound has not yet been established, although its anti-cancer activity has been reported in the last few years. ${ }^{10,11}$ In the present paper, we have isolated AGP (diterpenoids) from the aerial parts of Andrographis paniculata plant by column chromatography and repeated crystallization. The structure of the isolated compound was established by spectral analysis and screened against different types of cancer cell lines, namely NALM-6 (pre B-ALL), K562 (CML), A549 (lung carcinoma) and MCF-7 (breast carcinoma). NALM-6 appeared to be the most sensitive in response to AGP treatment in comparison to the other types of cancer cells, as evidenced by MTT assay. In this article we first time investigated the anti-apoptotic activity of AGP against NALM-6 which was established by cell cycle analysis and nuclear break down assay. 


\section{METHODS}

\section{Collection of plant materials}

The leaves of the plants were collected from the Garmirjapur village of West Bengal during the September- October of 2014 and identified by Prof. N. D. Paria, Department of Botany, University of Calcutta. Plant materials were air dried in the shade at a $35^{\circ} \mathrm{C}-40^{\circ} \mathrm{C}$ temperature for several days, so that no residual water remains in the sample. Dried samples were grounded into fine powder $(1 \mathrm{~kg})$ and stored in vacuum desiccator until use.

\section{Chemicals}

RPMI 1640 and fetal bovine serum (FBS) were purchased from GIBCO/ Invitrogen. Penicillin, streptomycin, DAPI, Propidium iodide and thiazolyl blue tetrazolium bromide (MTT) were purchased from SIGMA. Silica gel (100-200) and all the solvents, e.g. methanol, chloroform, petroleum ether used for column chromatography were purchased from Merck, India.

\section{Extraction and isolation of the compound}

$1 \mathrm{Kg}$ of powdered plant material of Andrographis paniculata was extracted with $95 \%$ methanol by a hot-extraction method using soxlet apparatus. The methanolic extract was evaporated using a rotary evaporator (BUCHI, Switzerland). Dried extract was defatted with petroleum ether. Defatted extract was subjected to silica gel (100-200 mesh) column chromatography (CC) and eluted with petroleum ether-chloroform mixtures (1:1 and 1:4) and chloroform-methanol mixture with gradually increasing polarity. 12 fractions were collected namely A-L. Fraction E, F and $\mathrm{G}$ were mixed up and subjected to $\mathrm{CC}$ using chloroform: methanol (98:2, 97:3) solvent system to yield AGP through repeated crystallization (approximately 1g) Figure 1. Pure crystals were colourless, solid, cube shaped and identified as AGP.

\section{Cell culture}

Human cancer cell lines NALM-6, K562, A549, MCF-7 were maintained in RPMI 1640 media supplemented with $10 \%$ heat-inactivated fetal bovine serum (FBS), $100 \mathrm{U} / \mathrm{ml}$ penicillin and $100 \mu \mathrm{g} / \mathrm{ml}$ streptomycin at $37^{\circ} \mathrm{C}$ in a humidified atmosphere of $5 \% \mathrm{CO}_{2}$.

\section{MTT assay}

Cells were seeded at a density $1 \times 10^{5}$ cells/well in 96-well microtitre plate and treated with AGP at different concentrations for $24 \mathrm{~h}$ and $48 \mathrm{~h}$ time points. After treatment, $20 \mu \mathrm{l}$ of $5 \mathrm{mg} / \mathrm{ml}$ MTT solution was added to each well and incubated for $4 \mathrm{~h}$ at $37^{\circ} \mathrm{C}$. After incubation, the medium was aspirated and formazan crystals produced in cells were solubilized in dimethylsulfoxide (DMSO). Absorbance was measured at $570 \mathrm{~nm}$ using a microplate reader (iMark, Bio-Rad, Japan). Results were expressed as a percentage of cell viability in comparison to control.

\section{Cell Cycle analysis}

NALM-6 cells in the exponential phase of growth were treated with AGP for $48 \mathrm{~h}$ time points, then washed, harvested, fixed by $70 \%$ ethanol and incubated for $30 \mathrm{~min}$ in PBS containing $100 \mu \mathrm{g} / \mathrm{ml} \mathrm{RNase}$ and $50 \mu \mathrm{g} / \mathrm{ml}$ propidium iodide (PI). For each sample, $10^{4}$ cells were analyzed on a flow cytometer (FACS Verse, Becton Dickinson, San Jose, CA, USA). Results were expressed as the percentage of cells in each phase of the cell cycle.

\section{Nuclear staining with DAPI}

Cells were seeded at a density $1 \times 10^{5}$ cells/well in 96-well microtitre plate and treated with AGP at different concentrations for $24 \mathrm{~h}$ and $48 \mathrm{~h}$. After treatment, cells were collected, washed with phosphate buffered saline (PBS) and permeabilized with methanol. DAPI $(1 \mu \mathrm{g} / \mathrm{mL}$ in PBS) was added and incubated for $15 \mathrm{~min}$ at room temperature. The stained cells were observed under a fluorescence microscope (Premium FL, Dewinter, Germany).

\section{RESULTS}

\section{Spectroscopic data of the isolated compound}

Andrographolide $\left(\mathrm{C}_{20} \mathrm{H}_{30} \mathrm{O}_{5}\right)$

${ }^{1} \mathrm{H}$ NMR $\left(\mathrm{C}_{5} \mathrm{D}_{5} \mathrm{~N}, 300 \mathrm{MHz}\right): \delta 7.18(1 \mathrm{H}, \mathrm{td}, J=1.5,7.0 \mathrm{~Hz}), 5.37(1 \mathrm{H}$, m), $4.88(1 \mathrm{H}, \mathrm{d}, J=1.0 \mathrm{~Hz}), 4.85(1 \mathrm{H}, \mathrm{d}, J=1.0 \mathrm{~Hz}), 4.60(1 \mathrm{H}, \mathrm{dd}, J=6.0$, $10.0 \mathrm{~Hz}), 4.50(1 \mathrm{H}, \mathrm{dd}, J=2.5,10.5 \mathrm{~Hz}), 4.43(1 \mathrm{H}, \mathrm{d}, J=10.5 \mathrm{~Hz}), 3.64-$ $3.60(2 \mathrm{H}, \mathrm{m}), 2.73(\mathrm{t}, J=7.0 \mathrm{~Hz}), 1.90(1 \mathrm{H}, \mathrm{m}), 1.51(3 \mathrm{H}, \mathrm{s}), 0.70(3 \mathrm{H}, \mathrm{s})$; ${ }^{13} \mathrm{C}$ NMR $\left(\mathrm{C}_{5} \mathrm{D}_{5} \mathrm{~N}, 75 \mathrm{MHz}\right) \delta 170.7,147.9,147.0,130.2,108.8,79.8,75.4$, 66.0, 64.1, 56.3, 55.3, 43.2, 39.1, 38.1, 37.3, 29.0, 25.0, 24.3, 23.7, 15.2. MS (ESI) $373.23[\mathrm{M}+\mathrm{Na}]{ }^{+}$Figure 2.

\section{Differential cytotoxic activity of Andrographolide}

We investigated the anti-proliferative effects of AGP against different cancer cell lines. Each cell line was treated with and without AGP for $24 \mathrm{~h}$ and $48 \mathrm{~h}$, followed by MTT assay. AGP exhibited cytotoxic activity against all the cell lines tested, but NALM- 6 was most sensitive. The IC values of AGP at 48h of incubation to NALM-6, K562, A549 and MCF-7 cells were $17 \mu \mathrm{M}, 25 \mu \mathrm{M}, 22 \mu \mathrm{M}$ and $21 \mu \mathrm{M}$ respectively. We found that cell viability after AGP treatment was decreased in a concentration and time dependent manner at both time points. We also tested the cytotoxic action of AGP against normal PBMC and found that AGP did not show any significant cytotoxic action against PBMC Figure 3. We further performed the nuclear fragmentation assay and cell cycle analysis with the most sensitive cell line NALM-6.

\section{Cell cycle analysis after AGP treatment}

To investigate the underlying mechanism of anti-leukemic activity of AGP, we performed cell cycle analysis after AGP treatment (control and $\mathrm{IC}_{50}$ value) by using flow cytometry after staining with Propidium Iodide. AGP mediated apoptosis was evidenced by the elevated number of sub G0/G1 cell population in comparison to the control set Figure 4, Table 1.

\section{Nuclear fragmentation analysis}

Occurrence of nuclear fragmentation, is one of the hallmark evidence of apoptosis. We performed DAPI nuclear staining after AGP treatment to NALM-6 cells to look at the nuclear fragmentation pattern. Results of DAPI staining indicated that exposure to AGP at $\mathrm{IC}_{50}$ values increased the number of fragmented nuclei and apoptotic body formation in the treated cells in comparison to the control set Figure 5.

\section{DISCUSSION}

In the present study, we isolated AGP from Indian medicinal plant Andrographis paniculata in a new protocol. At first we prepared the methanolic extract of the leaves, as it is reported to possess the most promising anti-cancer properties. ${ }^{12}$ This methanolic extract was run through the column chromatography using a combination of solvent system and isolated pure compound by repeated crystallization. The structure of the isolated compound was determined by spectral analysis.

Although extensive works have been performed to establish anti-cancer activity of AGP and its mechanism of action in several cancer types, ${ }^{13,14,15}$ anti-leukemic action of this diterpenoid has not yet been explored thoroughly. Therefore, we investigated the anti-leukemic activity of the isolated compound by studying its cytotoxic efficacy towards two leukemic cell lines viz. NALM-6, K562 along with A549 (lung carcinoma) and MCF-7 (breast carcinoma) as a positive control as it is sensitive towards the AGP. ${ }^{15}$ The result of the MTT assay showed a differential cytotoxic 


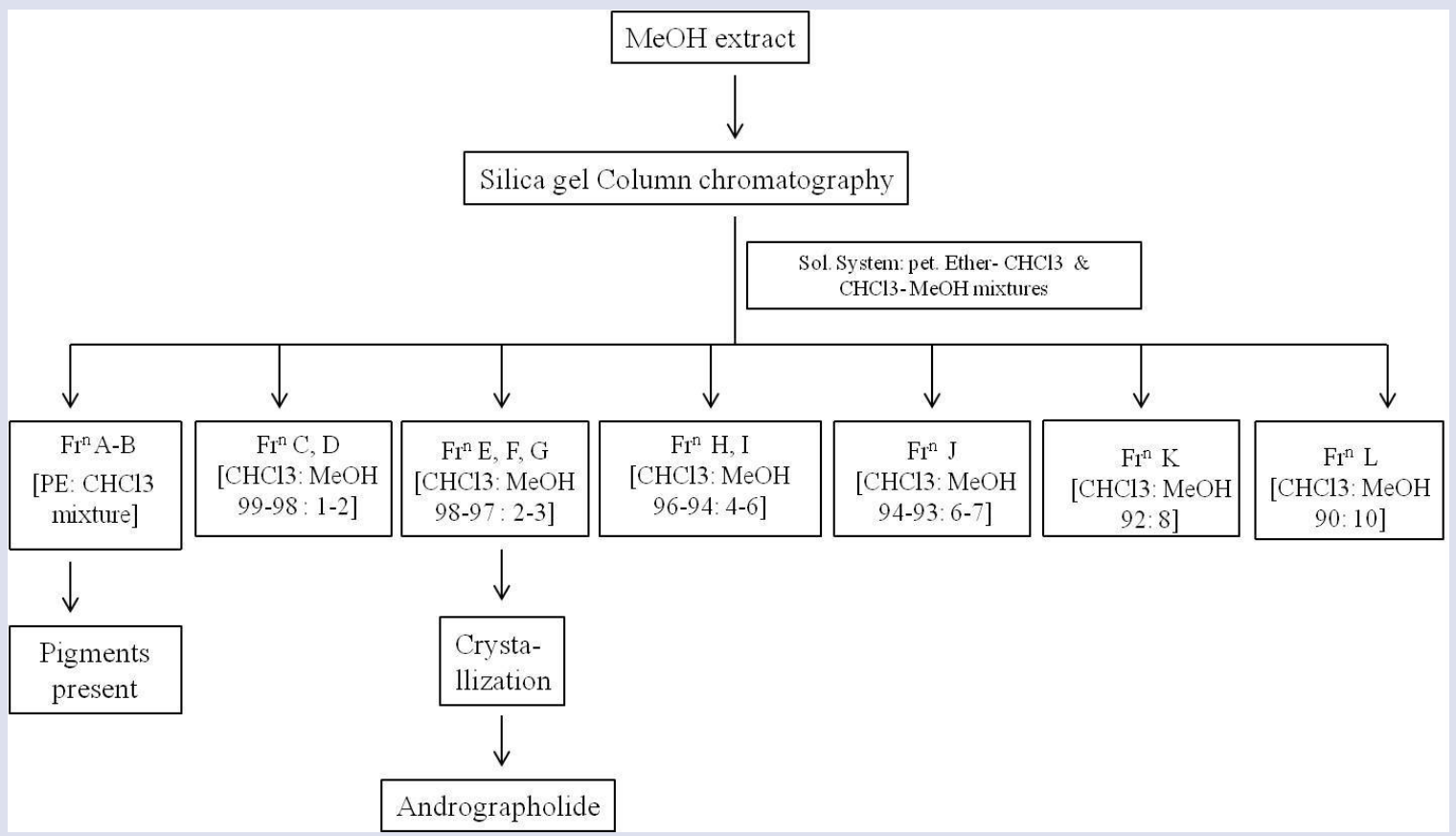

Figure 1: Schematic representation of isolation of AGP from the methanolic extract of Andrographis paniculata leaves through column chromatography.
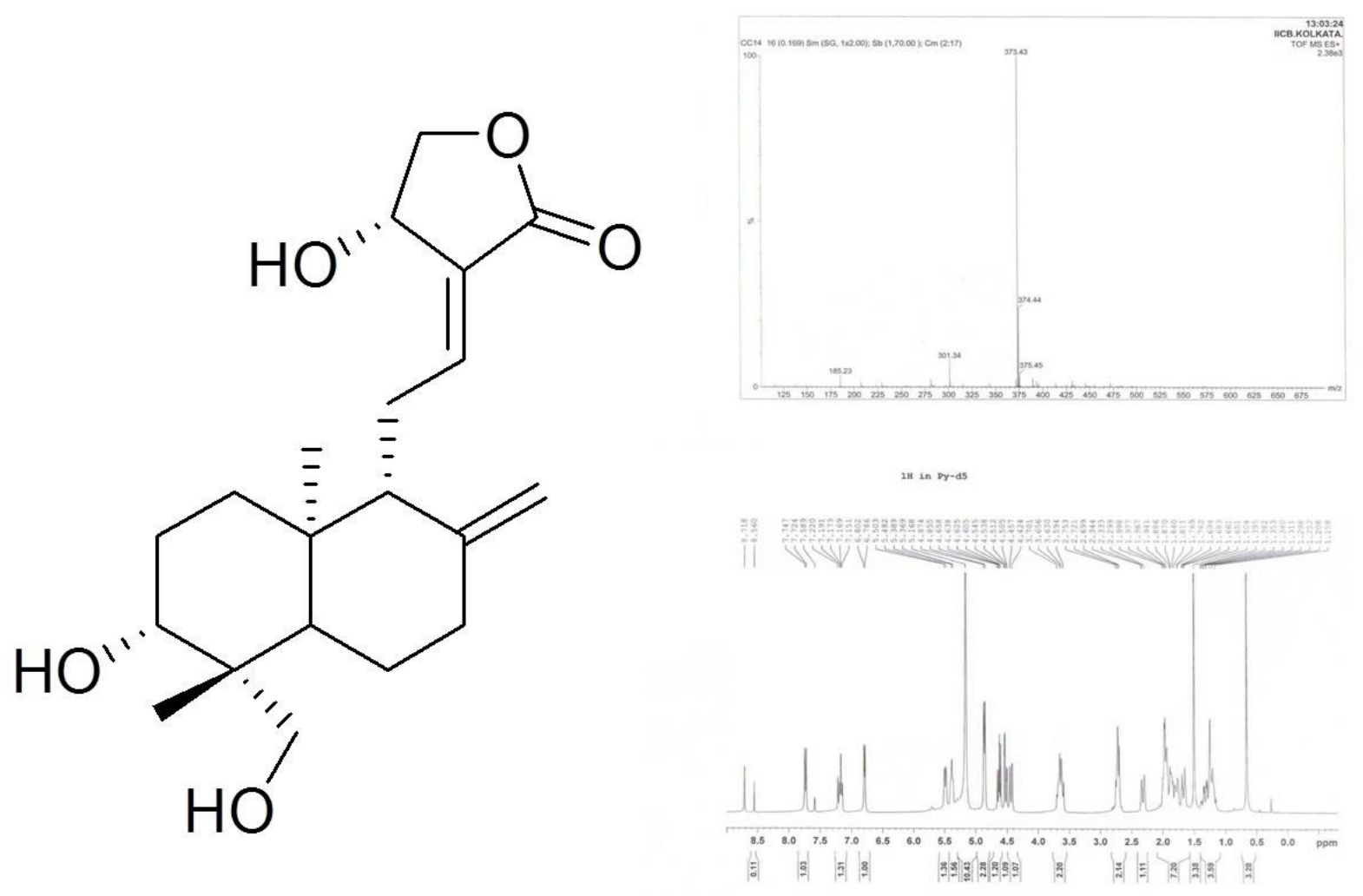

Figure 2: Chemical Structures of the isolated diterpenoid Andrographolide (AGP). 


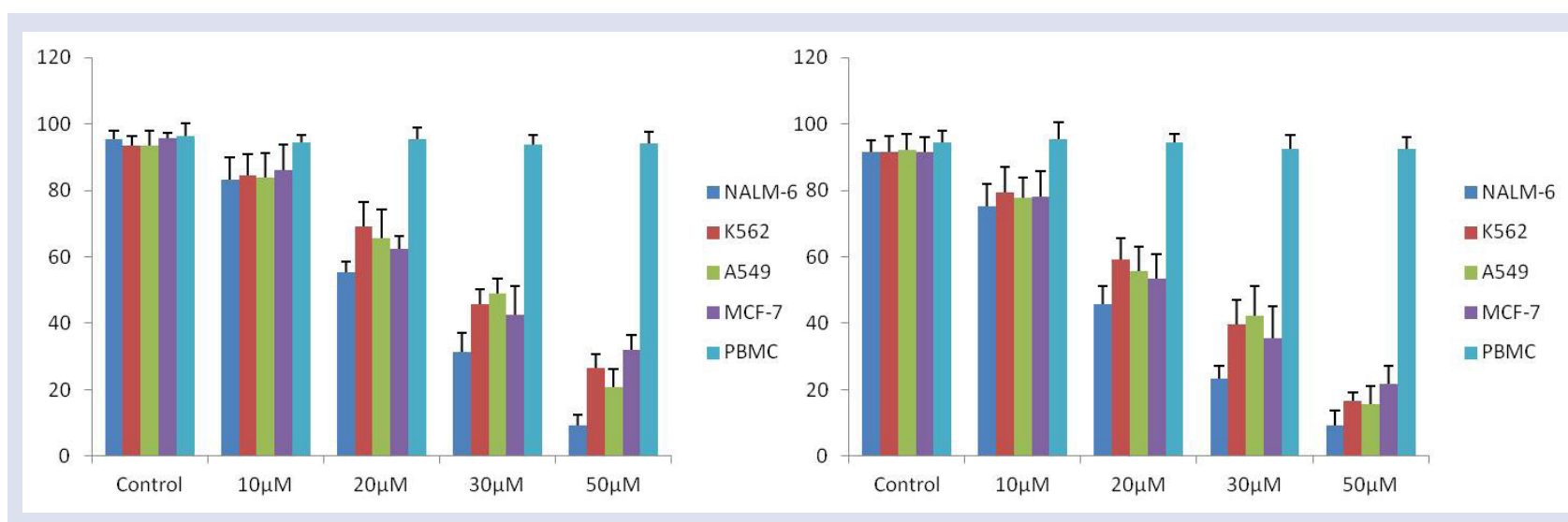

Figure 3: Assessment of anti-proliferative activities of the AGP against NALM-6, K562, A549, MCF-7 and PBM cells at $24 \mathrm{~h}$ and $48 \mathrm{~h}$ time points. Each line graph represents Mean \pm SD of three independent experiments.
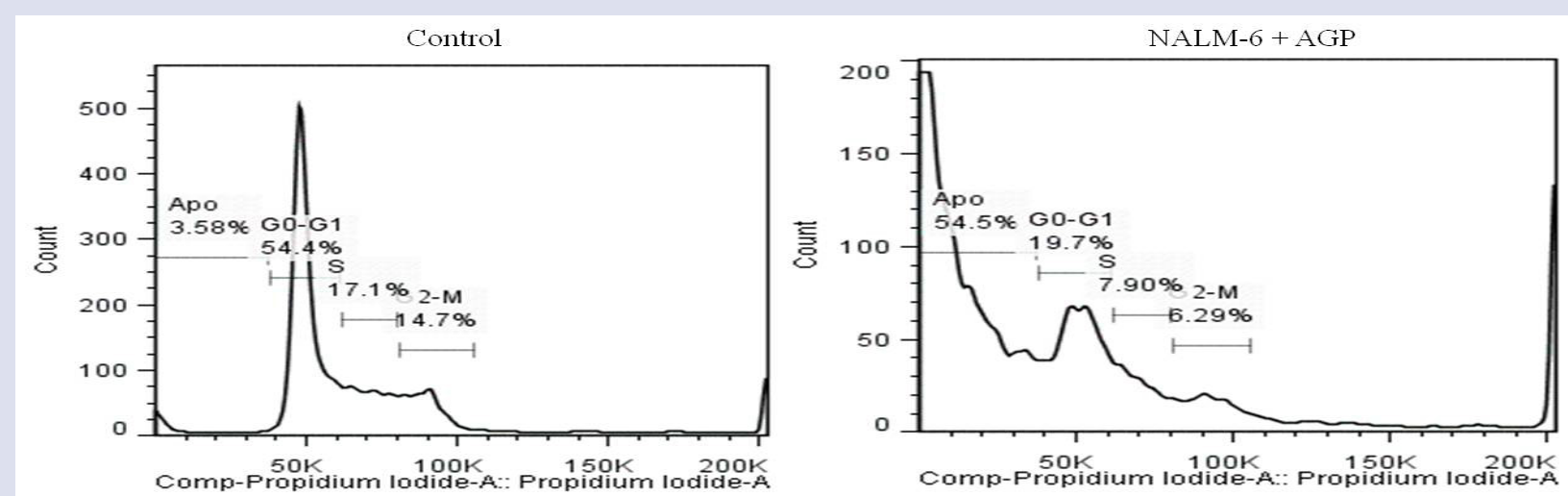

Figure 4: Cell cycle analysis of NALM- 6 cells after AGP treatment. NALM- 6 cells were treated with and without AGP (IC $\left.{ }_{50}\right)$ for 48 h and stained with Propidium lodide and analyzed by using a flow cytometer.
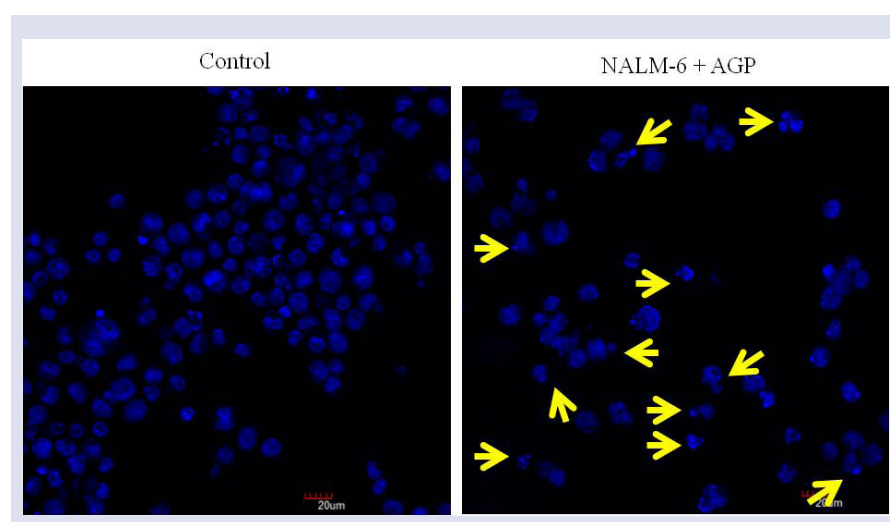

Figure 5: Detection of nuclear fragmentation in NALM-6 cells after AGP treatment. NALM- 6 cells were treated with and without AGP $\left({ }^{\prime} C_{50}\right)$ for $48 \mathrm{~h}$, stained with DAPI and visualized under fluorescence microscope.

activity of AGP towards four cancer cell lines and NALM-6 was found most sensitive. Therefore, we further explored the mechanistic detail of anti-cancer activity of AGP against most sensitive NALM- 6 cells. Apart from the anti-cancer activity, AGP interestingly exhibited nominal cytotoxicity towards the normal PBMC, which helped us to conclude that AGP has a potential to target the cancer cells leaving the normal healthy cells apart. Cell cycle arrest is one of the most promising evidence of apoptosis. Previous study entails that AGP effectively arrest cell cycle
Table 1: Cell cycle analysis of NALM-6 cells after AGP treatment

\begin{tabular}{ccccc}
\hline \multicolumn{5}{c}{ NALM6 + AGP } \\
\hline SET & Apoptosis & G0/G1 & S & G2/M \\
\hline Control & $3.84 \pm 2.6$ & $55.19 \pm 3.16$ & $16.03 \pm 1.84$ & $13.01 \pm 2.34$ \\
$10 \mu \mathrm{M}$ & $8.11 \pm 1.8$ & $53.35 \pm 3.83$ & $12.85 \pm 2.58$ & $12.10 \pm 1.57$ \\
$30 \mu \mathrm{M}$ & $54.75 \pm 1.11$ & $18.46 \pm 4.92$ & $9.51 \pm 2.56$ & $5.67 \pm 3.67$ \\
\hline
\end{tabular}

progression at $\mathrm{G} 0 / \mathrm{G} 1^{16}$ as well as $\mathrm{G} 2 / \mathrm{M}^{17}$ phase of the cell cycle. We performed cell cycle analysis of the AGP treated and untreated NALM-6 ells. Our result correlates with the Banerjee and her co-workers data and any G2-M arrest was not found. We further studied the nuclear fragmentation analysis because it is another hallmark event in apoptosis. We treated NALM-6 cells with AGP and after $48 \mathrm{~h}$ of incubation period, we visualized nuclei under a fluorescence microscope after staining with DAPI stain. We found an appreciable amount of cells with fragmented nuclei in comparison to the control untreated cells.

\section{CONCLUSION}

In conclusion, we can say that AGP, a diterpenoid isolated from Andrographis paniculata, effectively inhibited NALM-6 pre-B-ALL leukemic cells along with other cancer cells and thereby holds a great promise in 
its anti-leukemic potentiality and can be included in therapeutic interventions of leukemia treatment in the days to come.

\section{CONFLICT OF INTEREST}

The Authors have no conflict of interest

\section{ACKNOWLEDGEMENT}

The authors are indebted to Department of Science and Technology (Government of West Bengal); Department of Biotechnology (Government of West Bengal), UGC-UPE and UGC-CAS programme at the Department of Botany, University of Calcutta for financial support.

\section{ABBREVIATIONS USED}

LC-MS: Liquid chromatography-Mass spectrometry; NMR: Nuclear magnetic resonance; B-ALL: B-cell acute lymphoblastic leukemia; CML: Chronic myeloid leukemia; DAPI: 4,6-diamidino-2-phenylindole; Bcl2: B-cell lymphoma 2, Bcl-XL: B-cell lymphoma-extra large; FITC: Fluorescein isothiocyanate; PI: Propidium iodide; RPMI: Roswell Park Memorial Institute, PBS: Phosphate buffered saline; AGP: Andrographolide.

\section{REFERENCES}

1. Cancer Research UK. Leukemia (all subtypes combined). http://www.cancerresearchuk.org/health-professional/cancer-statistics/statistics-by-cancer-type/ leukemia (accessed 12.08.2017).

2. Tang W, Eisenbrandt G. Chinese drugs of plant origin: chemistry, pharmacology, and use in traditional and modern medicine. Springer-Verlag: New York. 1992.

3. Pholphana N, Rangkadilok N, Thongnest S, Ruchirawat S, Ruchirawat M, Satayavivad J. Determination and variation of three active diterpenoids in Andrographis paniculata (Burm.f.) Nees. Phytochem Anal. 2004;15(6):365-71.

4. Trivedi NP, Rawal UM, Patel BP. Hepatoprotective effect of andrographolide against hexachlorocyclohexane-induced oxidative injury. Integ Can Ther 2007;6(3):271-80.

5. Xia YF, Ye BQ, Li YD, Wang JG, He XJ, Lin X, et al. Andrographolide attenuates

inflammation by inhibition of NF-kappa $B$ activation through covalent modification of reduced cysteine 62 of p50. J Immunol. 2004;173(6):4207-17.

6. Coon JT, Ernst E. Andrographis paniculata in the treatment of upper respiratory tract infections: a systematic review of safety and efficacy. Planta Med. 2004;70(4):293-8.

7. Cheung HY, Cheung SH, Li J, Cheung CS, Lai WP, Fong WF, et al. Andrographolide isolated from Andrographis paniculata induces cell cycle arrest and mitochondrial-mediated apoptosis in human leukemic HL-60 cells. Planta Med. 2005;71(12):1106-11.

8. Yoopan N, Thisoda P, Rangkadilok N, Sahasitiwat S, Pholphana N, Ruchirawat S, et al. Cardiovascular effects of 14-deoxy-11, 12-didehydroandrographolide and Andrographis paniculata extracts. Planta Med. 2007;73(6):503-11.

9. Tzeng YM, Lee YC, Cheng WT, Shih HN, Wang HC, Rao YK, et al. Effects of andrographolide and 14-deoxy-11, 12-didehydroandrographolide on cultured primary astrocytes and PC12 cells. Life Sci. 2012;90(7):257-66.

10. Ooi JP, Kuroyanagi M, Sulaiman SF, Muhammad TS, Tan ML. Andrographolide and 14-deoxy-11, 12-didehydroandrographolide inhibits cytochrome P450s in HepG2 hepatoma cells. Life Sci. 2011;88(9):447-54.

11. Tan ML, Tan HK, Oon CE, Kuroyanagi M, MuhammadTS. Identification of genes involved in the regulation of 14-deoxy-11,12-didehydroandrographolide-induced toxicity in T-47D mammary cells. Food Chem Toxicol. 2012;50(2):431-44.

12. Kumar RA, Sridevi K, Kumar NV, Nanduri S, Rajagopal S. Anticancer and immunostimulatory compounds from Andrographis paniculata. J Ethnopharmacol. 2004;92(2-3):291-5.

13. Chen W, Feng L, Nie H, Zheng X. Andrographolide induces autophagic cell death in human liver cancer cells through cyclophilin D-mediated mitochondrial permeability transition pore. Carcinogenesis. 2012;33(11):2190-8.

14. Yang S, Evens AM, Prachand S, Singh AT, Bhalla S, David K, et al. Mitochondrialmediated apoptosis in lymphoma cells by the diterpenoid lactone andrographolide, the active component of Andrographis paniculata. Clin Cancer Res. 2010;16(19):4755-68.

15. Li J, Zhang $\mathrm{C}$, Jiang $\mathrm{H}$, Cheng J. Andrographolide inhibits hypoxia-inducible factor-1 through phosphatidylinositol 3-kinase/AKT pathway and suppresses breast cancer growth. Onco Targets Ther. 2015;8:427-35.

16. Banerjee M, Chattopadhyay S, Choudhuri T, Bera R, Kumar S, Chakraborty B, et al. Cytotoxicity and cell cycle arrest induced by andrographolide lead to programmed cell death of MDA-MB-231 breast cancer cell line. J Biomed Sci. 2016;23(1):40.

17. Li J, Cheung HY, Zhang Z, Chan GK, Fong WF. Andrographolide induces cell cycle arrest at G2/M phase and cell death in HepG2 cells via alteration of reactive oxygen species. Eur J Pharmacol. 2007;568(1-3):31-44.

\section{SUMMARY}

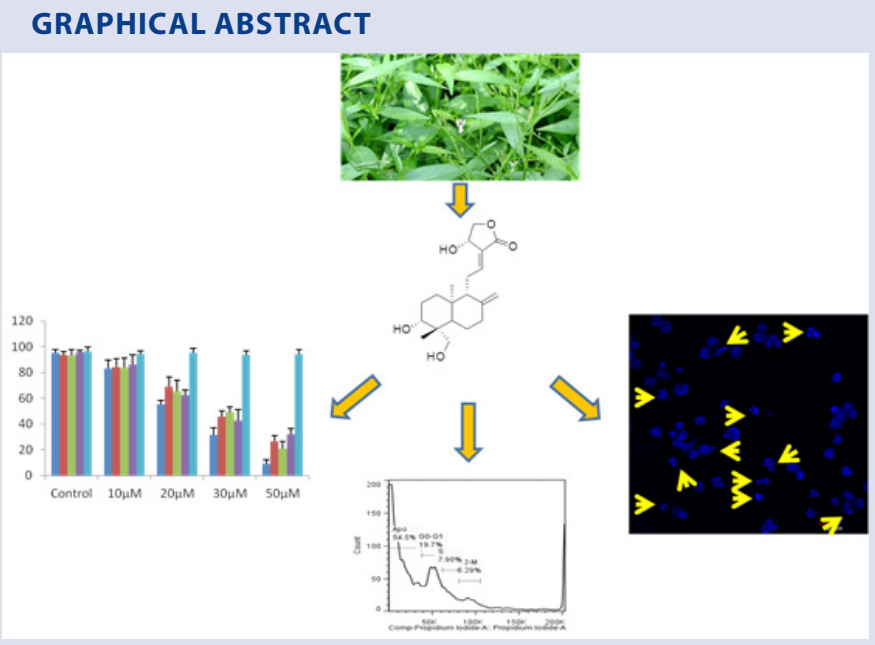

- Andrographolide was isolated from Andrographis paniculata.

- It was able to induce cytotoxicity in four different cancer cell lines, namely NALM-6, K562, A549 and MCF-7; among which NALM-6 was most sensitive to Andrographolide with $I C_{50}$ values of $17 \mu \mathrm{M}$.

- Andrographolide effectively arrested cell cycle progression at a G0-G1 phase in NALM-6 leukemic cells.

- It also induced nuclear fragmentation in NALM-6 cells, which was evidenced by DAPI staining and fluorescence microscopy.

\section{ABOUT AUTHORS}

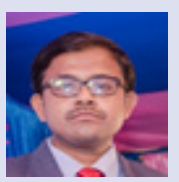

Swadesh Sarkar: Is an Assistant professor at the Department of Botany; Chandernagore College; West Bengal, India.

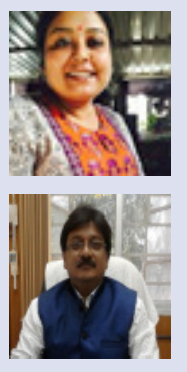

Priya K Gopal: Is a Senior Research Fellow of Laboratory of Cell and Molecular Biology at the CAS, Department of Botany; University of Calcutta; West Bengal, India.

Dr. Santanu Paul: Is an Associate Professor at the Department of Botany; University of Calcutta; India. Has experience in isolation and characterization of anti cancerous novel compounds from medicinal plants and looking at the molecular mechanism of apoptosis induction.

Cite this article: Sarkar S, Gopal PK, Paul S. Andrographolide Induced Apoptosis in NALM-6 Cells Mediated Through the Cell Cycle Arrest and Nuclear Fragmentation. Pharmacog J. 2018;10(2):210-4. 